\title{
越流型単独水制の流れの抵抗に関する研究 STUDY ON FLOW RESISTANCE FOR SUBMERGED SINGLE GROYNE
}

\author{
門田章宏 1 - W. S. J. Uijttewaal ${ }^{2}$ \\ Akihiro KADOTA and W. S. J. Uijttewaal \\ 1正会員 博(工) 愛媛大学大学院准教授 理工学研究科生産環境工学専攻( テ 790-8577 松山市文京町3) \\ 2 Professor, Faculty of Civil Engineering and Geosciences, Delft University of technology \\ (5 2600 AA Delft, Netherlands)
}

\begin{abstract}
Groynes have been used for the protection of banks, stabilization of bed morphology and also for establishing navigation channels. A typical Japanese river is characterized by large and sudden variations in discharge due to big amounts of rainfalls, so that the groynes are often in submerged condition. The present study focuses on the effects of submergence on the mean flow pattern and resistance around a single groyne. The PTV method and numerical shallow flow analysis are adopted in order to calculate velocities accurately. The flow pattern and flow resistance are estimated by comparing velocities at several points between upstream and downstream of groyne. The relations between flow resistance and submerged flow depth are discussed in the present study
\end{abstract}

Key Words: Drag force, PTV, Shallow flow visualization, submerged effects Analyses of $2 D$ shallow flow, Roughness coefficient

\section{1. はじめに}

流れの境界に存在する水制構造物は様々な役割を持ち, ドイツ・ライン川やエルベ川においては主に貨物船等の 船舶の航行に必要な航路の確保に水制が使われている. その他，護岸や水生生物にとっての環境改善の目的でも 用いられている. この様に様々な水制の役割を持つこと から，水制周辺の流れの研究は良好な環境の保全や洗掘 防止のための護岸対策，低水路における水深の確保のた めの最適な水制のデザインを目的として行われてきた.

河川・海岸における水制や橋脚等の水理構造物周辺の 流れや洗掘現象に関する研究は, 実験的にまた数值計算 においても従来盛んに行われてきており，これら構造物 周辺の污染物質の拡散現象や土砂輸送等についても以下 に述べる代表的な研究が幾つか行われている.

水制周辺の流れや洗掘現象に関するこれまでの主な研 究に関しては，水制間の距離と水制長さで表したアスペ クト比と主流域・死水域間の混合層や渦構造との関係に 着目した研究がChen\&Ikeda ${ }^{1}$, Kimura\&Hosoda ${ }^{2}$, Uijttewaal ら3)等によって行われ，中でも染料による可視化実験に よって混合層内の物質交換現象に関する研究が Altai\&Chu'), Uijttewaal ( ${ }^{3)}$, Weitbrecht\&Jirka ${ }^{5)}$ にって詳 細に行われている. 一方, 水制先端付近の流孔構造と洗

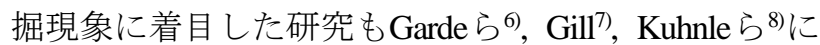
よって古くから行われている. その他，先述した河川環 境に関する目的や水制先端付近の洗掘防止のための乱れ の制御等に対する最適な水制デザインを提案した研究が

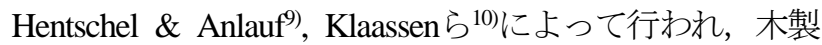
による透過性の水制や水制の勾配を変えて最適な横断面 形状を提案した研究も存在する。 また，流れの現地観察 もSukhodolovら11)により行われている.

上述の既往研究に加え, 水制構造物を物体と捉え, 水 制上部を越流寸る流れに関寸る抗力係数を評価する研究 が近年行われている. Maurits ${ }^{12)}$ は，Waal川に現存する越 流型連続水制が水位変化に与える影響について，従来か ら提案されている水制構造物の抗力係数との関係を表す 経験式について数值解析により検討を行っており，代表 的な幾つかの抗力係数の式13,14,15)を用い，水深，フルー ド数，水制形状を変化させて各々の式の特徽や適用性を 検討している.

一方，日本の主な気象・河川特性として挙げられるの は，降雨量の季節的変動が大きく，流路が短く急峻であ ることである．近年観察される様々な自然現象は，温暖 化による影響と併せて, 突発的な豪雨・洪水が多く, 水 制等の河川構造物周辺の流れは度々越流状態になり，水 位上昇に伴う河岸浸食や越流汇濫対策のため，水制周辺 の越流状態を詳細に把握し予測する必要がある．本研究 


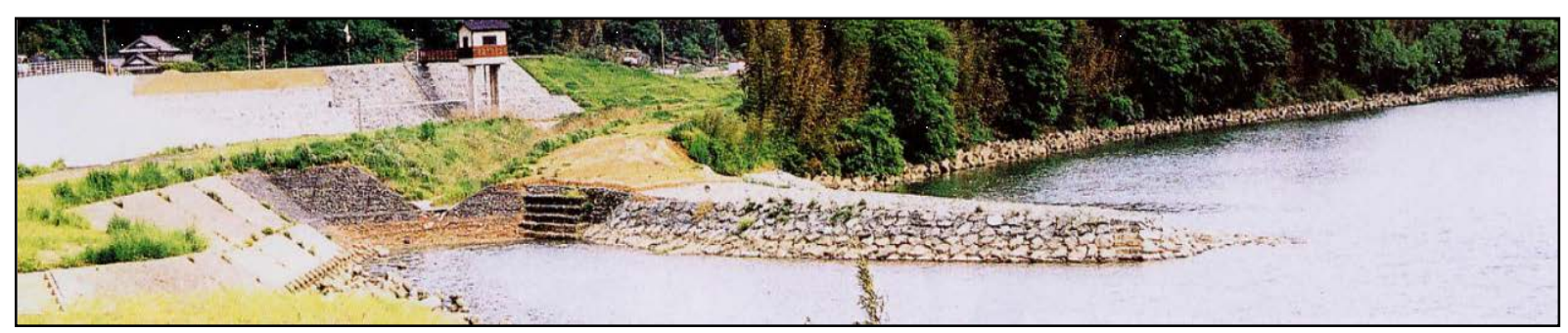

写真-1 肱川河口から18.8km地点にある越流水制

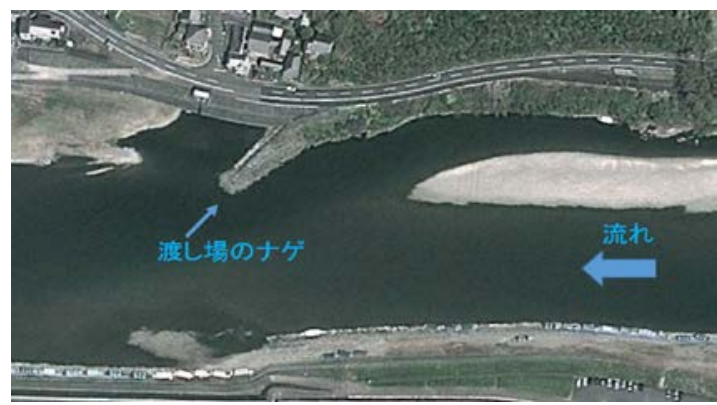

写真-2 肱川水制(ナゲ)の周辺

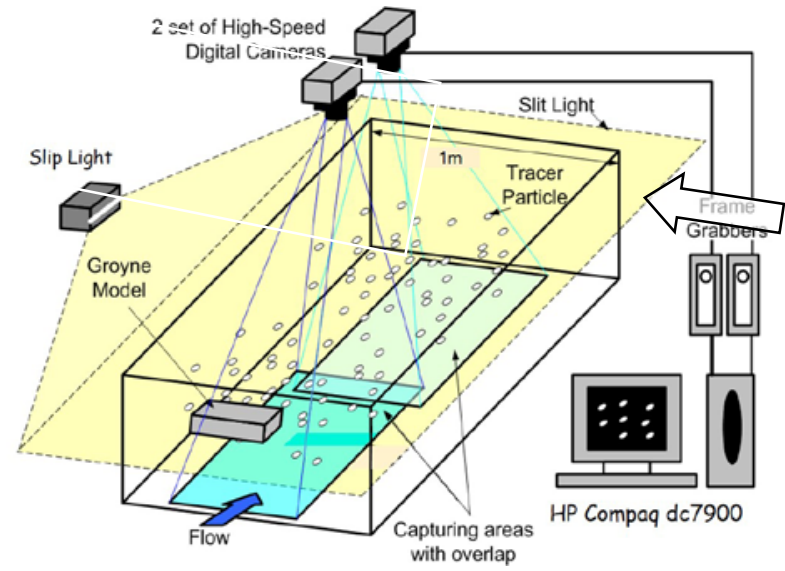

図-2 可視化実験装置

では，愛媛県西部にある大洲市の中心を流れる肱川にあ る「ナゲ」と呼ばれる越流型水制工を対象とした．肱川 流域は河口が狭く, 河床勾配が緩く浸水汇濫が起きやす い地形で, 肱川の水制は出水毎に越流状態を繰り返して いる. 本研究では, 縮小模型による浅水流可視化実験を 行い，水制周辺の平面流れおよび水位を計測した．また， 従来から提案されている水制構造物による抗力係数の代 表的な経験式から，マニングの粗度係数を求める式を新 たに導入し, 平面二次元流解析に粗度係数を適用するこ とにより，水制周辺の越流流れの再現性の検討を行うこ とを目的とした。

\section{2. 水理条件および浅水流可視化実験手法}

\section{（1）愛媛県肱川にある水制(ナゲ)}

本研究で対象とする愛媛県肱川にある水制は江戸時代 約300年前に造られ古来より現存する河川構造物で, 治 水，軍事目的に使用されてきた不透過水制である. 写真 -1は，現存寸る8水制の中で河口から上流18km地点にあ

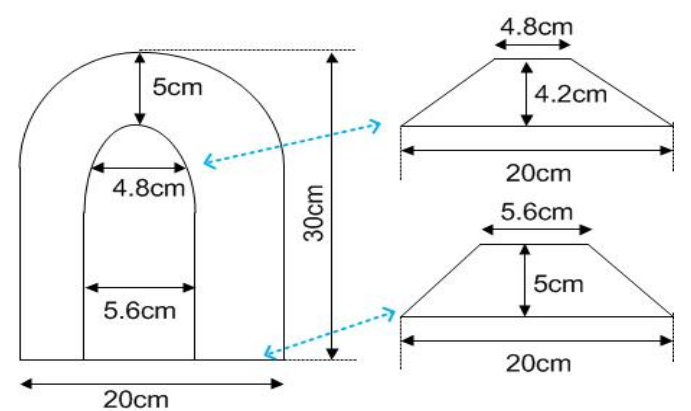

図-1 水制模型（左:平面図，右:断面図)

る渡場のナゲと呼ばれる水制である，肱川の最も大きな 特徵として, 河口部が狭く, 支川が多いことから出水時 には水が溜まりやすく別けにくいという点が挙げられる. このため，これらの水制は大きく水深変化の影響を受け， その周辺の流れは大きく変化する. 本研究では, この肱 川にある水制を対象として縮小模型を作成し浅水流可視 化実験を行った．写真-2は，写真-1で示した肱川水制を 上空から撮影した写真である. 水制は河幅 $115 \mathrm{~m}$ に対し 長さ約35m, 幅約 $12 \mathrm{~m} の$ 突堤状の形状からなり上流湾曲 部からの偏流に対して直角に設置された水制である.

\section{（2）実験条件および実験方法}

図-1に示寸本研究で用いる水制模型は，渡し場のナゲ の横断方向, 水深方向の遮蔽率が等しい形状であり, 横 断方向の水制長の $35 \mathrm{~m}$ に対し, 河幅 $115 \mathrm{~m}$ であるため横 断方向の遮蔽率は $30 \%$ ，水制の高さ5.5mであるため河幅 との比は5\%である. 従って, 水制のスケールは, 水路 幅 $1.0 \mathrm{~m}$ に対して, 下端幅 $20 \mathrm{~cm}$, 天端幅 $5.6 \mathrm{~cm}$, 水制長 $30 \mathrm{~cm}$, 高さ $5 \mathrm{~cm}$ とした. 水制, 天端部の先端部は丸みを 帯び，水制法面の傾きは1:1.2となっている.

本実験で使用した装置は，図-2に示寸直線型循環式開 水路(長さ $8 \mathrm{~m}$, 幅 $1 \mathrm{~m}$, 高さ40cm), 高速CCDカメラ(DITECT HAS-220)を2台, カメラ設置のフレーム(MZCアルファ フレーム), 水深調節堰, 画像取得用 PC(HP Compaq dc7900)から構成されている. 本実験で用いたトレーサ 粒子(ポリプロピレン, 比重0.98)は静電気による粒子の 吸着を防ぐため界面活性剂を使用した。

実験条件を表-1に示寸．実験条件の設定にあたって， 水制周辺に現れる越流水深の変化が及ぼす流れの影響を 考慮するため, 水深 $h=6 \sim 10 \mathrm{~cm}$ の計4ケースと段階的に 変化させ，本実験の流量を肱川橋付近で観測された出水 流量規模(約 $\left.400 \mathrm{~m}^{3} / \mathrm{s}\right)$ のFroude数を基淮に, 断面平均流速 $(12.5 \mathrm{~cm} / \mathrm{s})$ を一定とし段階的に変化させた. 
表-1 実験条件

\begin{tabular}{|l|c|c|c|}
\hline case & 水深 $(\mathrm{cm})$ & $\begin{array}{c}\text { 流量 } \\
\text { (liters/s) }\end{array}$ & $\begin{array}{c}\text { 主流域 } \\
\text { Froude数 }\end{array}$ \\
\hline 1 & 6.0 & 7.50 & 0.163 \\
\hline 2 & 7.0 & 8.75 & 0.151 \\
\hline 3 & 8.0 & 10.00 & 0.141 \\
\hline 4 & 10.0 & 15.00 & 0.126 \\
\hline
\end{tabular}

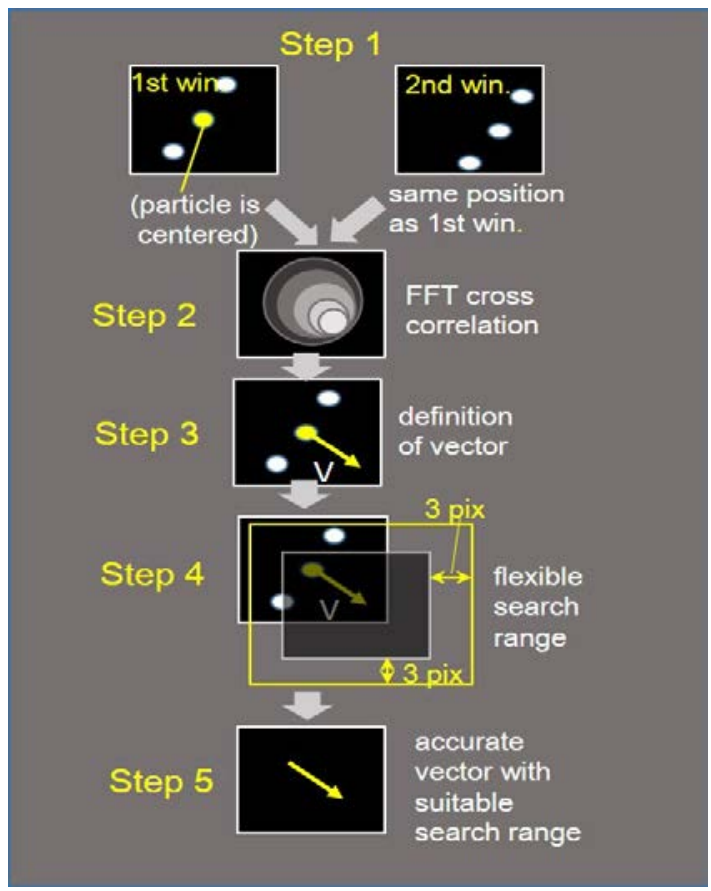

図-3 FFTおよび直接相互相関の可視化画像解析

浅水流可視化実験における可視化画像の撮影手順として は，広域の撮影で画像の精度を確保するため上述した2 台の高速度カメラを上流から $3.5 \mathrm{~m} に$ ある水制模型の上下 流側にそれぞれ設置し上空から水表面上の粒子画像の撮 影を行った. 1台のカメラの撮影領域は $640 \times 480$ ピクセ ル (1pixel $=0.0125 \mathrm{~cm})$ で上流側・下流側カメラで同じ領域 をオーバーラップさせてポリプロピレン粒子を均等に撒 布した後，撮影を開始した。粒子画像の撮影は $100 \mathrm{~Hz}$ 約24秒間，2台のカメラで4806枚の画像を取得した. そ の後，二枚の画像をそれぞれ結合することで $1265 \times 456$ ピクセルの連続画像を本研究グループが開発したPTV法 により解析を行った。

PTV法の解析の流れの概要を図-3に示している. Step1で同時撮影された2枚の画像をStep2にてFFT相互相 関解析を行い, Step3で画像のずれを求め, このずれを 仮の流速ベクトルと仮定し，Step4で，そのベクトルの 先端を中心として，再度直接相互相関によってより精度 の良い流速值およびベクトルをStep5にて評価する.

\section{3. 水制構造物の抗力係数 - 粗度係数の評価手順}

（1）水制構造物としての抗力係数の算定式 上述したように水制構造物を流体の中に存在する物体
表-2 越流水制構造物抗力係数の実験公式

\begin{tabular}{|l|c|}
\hline $\begin{array}{l}\text { Yossef } \\
\text { (2005) }\end{array}$ & $C_{d}=F_{r m c}^{2} 76.4\left(\frac{h_{g}}{d}\right)^{3.7}$ \\
\hline $\begin{array}{l}\text { Van } \\
\text { Broekhoven } \\
(2007)\end{array}$ & $C_{d}=1.74\left(\frac{h_{g}}{d}\right)^{2}-0.08\left(\frac{h_{g}}{d}\right)+0.07$ \\
\hline $\begin{array}{l}\text { Azinfar } \\
(2010)\end{array}$ & $C_{d}=1.62\left(1-\frac{L h_{g}}{B d}\right)^{-2.4}\left(\frac{h_{g}}{L}\right)^{-0.32}\left(\frac{d}{h_{g}}\right)^{-0.19}$ \\
\hline
\end{tabular}

$C_{d}$ :抗力係数, $h_{g}$ :水制高, $L:$ 水制長, $B$ :水制幅 $d$ :水深, $F r_{m c}$ :主流域のFroude数,

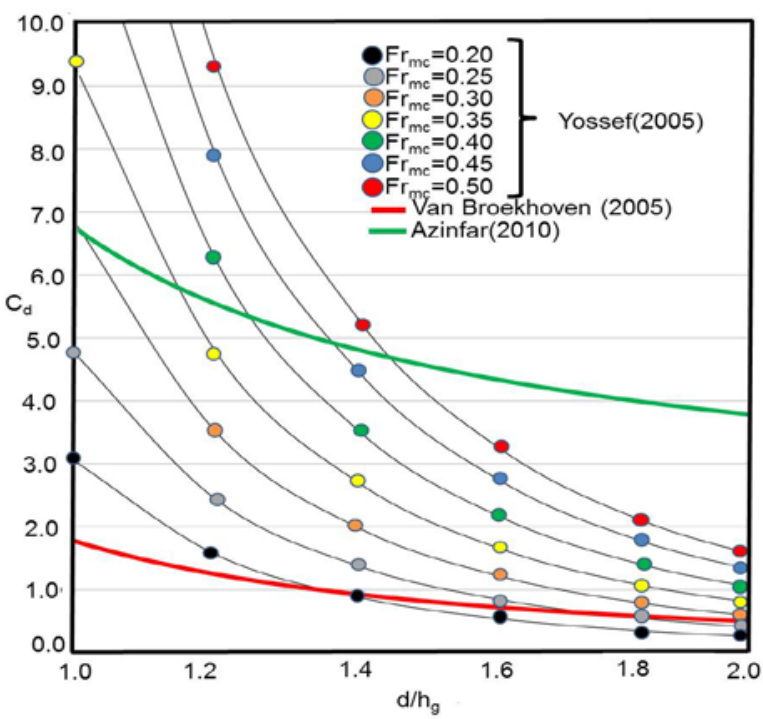

図-4 実験公式による抗力係数と水制高 - 水深比

として，抗力係数 $\left(C_{d}\right)$ を求める算定式が幾つか提案され ている．表-2に水制高さ(hg)を一定とした水制上を越流 する水深 $(d)$ の関数として表す三つの代表的な式を示して いる.これらの算定式は，水制表面の摩擦による抵抗を 評価したものである. Yossef ${ }^{13)} は ，$ 越流型連続水制が流

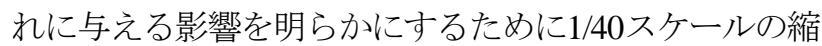
小模型で流速計測を行い，実験的に水制の抗力係数の式 を求めた。水路を水制領域と主流領域の2つの領域に分 割し，水制の抗力係数は，主流領域のフルード数と水制 の高さに対する水深の比を変数とする関数で表わすこと が可能と仮定した. Van Broekhoven ${ }^{14)}$ は, 数值流体解析 を用い，越流水制周辺の流れを明らかにし，水制の抗力 係数の式を求めた。得られた解析結果から連続水制の 個々の流れに対する影響を明らかにし，単一の水制の抗 力係数の式は，水制の高さに対する水深の比のみを用い て表わすことが可能と提唱した. Azinfarr15)は，Yossef と 同様に，水理模型実験から水制の抗力係数を求めた.

Azinfarの水理模型実験は，薄い板を水制模型として用い, 直接測定した水制周辺の流況から，運動量の式を用いて 計算された值に適するように水制の抗力係数の式を定め た.

本研究では，これらの抗力係数の式の適用性について 検討を行った. 図-4には，表-2から評価した抗力係数 

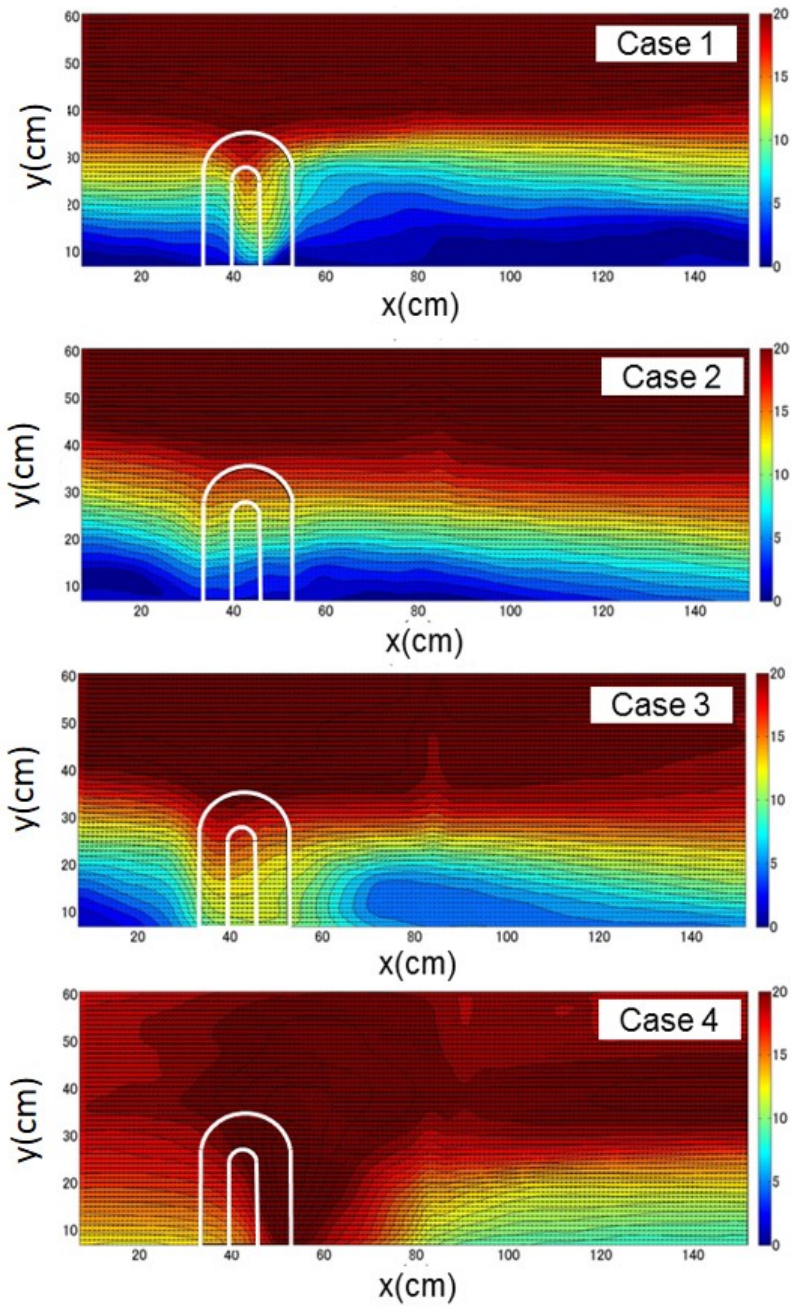

図-5 浅水流可視化実験の水表面主流方向流速成分 $(\mathrm{cm} / \mathrm{s})$

$\left(C_{d}\right)$ と水深・水制高さ比 $\left(d / h_{g}\right)$ の関係を示している. Yossefの式については主流域のフルード数 $\left(F r_{m c}\right)$ が含まれ ているため常流となる $0.2 \sim 0.50$ 範囲で示している. そ の他の2式については表-2に示されているように水深d 水制高さhgのみの関数である. これらの三つの式を比較 すると，VanとYossefの式のFr $r_{m c}=0.2$ 付近が本実験の条件 や肱川の流量規模と相応することから，この2式が適用 可能と判断できる. 本研究では，この二式の中で，越流 水深比 $\left(h_{g} / d\right)$ で現されるVanによる抗力係数の式を適用し 以下の手順に従って水制粗度を求めた.

\section{（2）水制構造物の抵抗および粗度係数の導出}

上述の越流水型水制構造物の抵抗係数 $\left(C_{d}\right)$ の算定式は, 越流する流れに関する抗力係数を評価したもので，実際 の流れ現象について適用性の検討が欠けている. また, 求めた抗力係数は流れの計測から容易に得られるが，実 務計算では流れや河床変動解析に直接的に適用すること は困難である.また，流れや河床変動の数值解析におい ては，マニングの粗度係数が流れに対する摩擦抵抗とし て取り扱われるため，水制構造物による抵抗も同様な取 り扱いが望ましい，そこで，本研究では，次の手順に 従って，抗力 $(D)$ からマニングの粗度係数 $(n)$ を求めた.
まず抗力 $D$, 上述の算定式から求められる抗力係数 $C_{d}$ を用いて以下の式により求める.

$$
D=\frac{1}{2} \rho C_{d} A_{d} V_{d}^{2}
$$

ここで, $\rho$ =密度, $A_{d}=$ 抗力 $D$ が作用する面積, $V_{d}=$ 水制上流 側の平均流速であり，PTV計測結果によって評価される。 次に, 式(1)で求められた抗力Dから, 摩擦速度 $\left(U_{*}\right)$ およ び河床せん断応力 $\left(\tau_{b}\right)$ を以下の二式から求める.

$$
u_{: *}=\sqrt{\frac{D}{\rho A_{d}}} \quad \text { (2) および } \tau_{b}=\rho u_{*}^{2}
$$

また，河床せん断応力 $\left(\tau_{b}\right)$ は，摩擦損失係数 $f$ やエネ ルギー勾配 $I_{e}$ を用いて，それぞれ，以下のように表す ことができる.

$$
\frac{\tau_{b}}{\rho} \equiv \frac{f}{8} V_{d}^{2} \quad \text { (4) } \quad \text { および } \tau_{b}=\rho g d I_{e}
$$

ここで， $g$ =重力加速度である. 従って式(1)〜(4)から $f=4 C_{d}$ となる. さらにマニングの式は以下で表される.

$$
V_{d}=\frac{1}{n} d^{2 / 3} I_{e}^{1 / 2}
$$

ここで， $d=$ 水深である. 式(4),(5)および式(6)から，摩擦 損失係数 $f$ とマニングの粗度係数 $n$ との関係が以下のよ うに求められる.

$$
f=\frac{8 g n^{2}}{d^{1 / 3}} \quad \text { (7) より } n=\sqrt{\frac{f}{8 g}} d^{1 / 6}
$$

前述で適用性を検討した抗力係数 $C_{d}$, 式(1) (3)により 求まる $\tau_{b}, f$ を式(6)と併せて求め, 式(8)で求められた マニング粗度係数が抗力係数 $C_{d}$ から求めることが可能と なり，本研究では，平面二次元流解析に適用することで， この手順で求めた水制粗度の流れの再現性を検討した.

\section{4. 可視化実験と平面二次元流解析の再現性}

水制周辺の流れの解析にあたつては，浅水流可視化実 験に適用可能なiRIC Nays2Dを用いた。本実験で実施し た水路，水制模型サイズ・位置，水理条件に関しては全 て同条件とし，流下方向，横断方向に0.02m毎に区切り， 合計で20451個のメッシュに分割した。各グリッド上に 図-1で示した水制形状を再現し，その水制構造物表面に 上述した粗度を与えて解析を行った. 水制位置について も上流部から $3.5 \mathrm{~m}$ 地点に配置している. 図-5は，表-1に 示した実験条件に従って行った浅水流可視化実験の水表 面上の主流方向流速成分の結果を示したものである. 


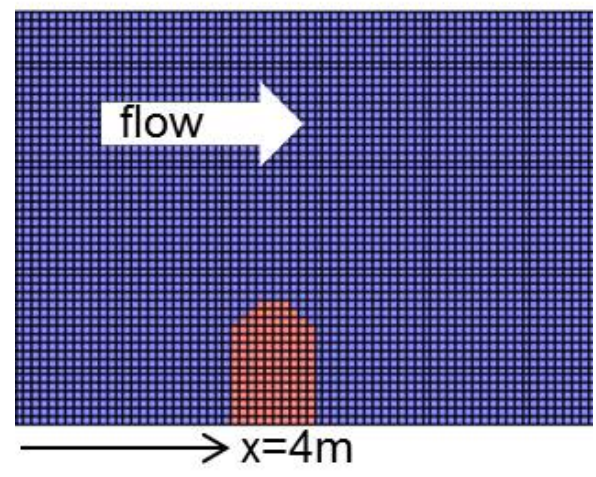

図-6＼cjkstart対象とした水制構造物周辺の 計算メッシュ(間隔 $1 \mathrm{~cm})$ と水制位置

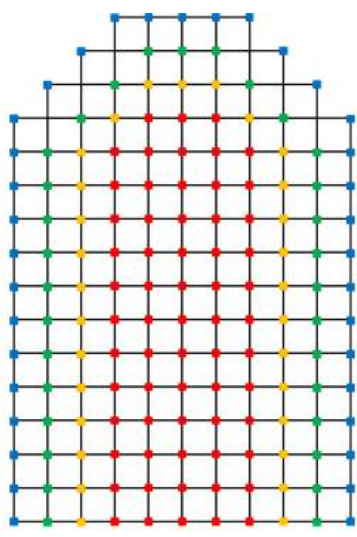

nurface area $y=5.0 \mathrm{~cm}$

slope area (1) $y=3.3 \mathrm{~cm}$ - slope area (2) $\mathrm{y}=1.6 \mathrm{~cm}$ - slope area (3) $\mathrm{y}=0.0 \mathrm{~cm}$

図-7＼cjkstart水制構造物表面の粗度係数の設定領域

表-3 越流水深 $(d)$, 抗力係数 $(C d)$, 抗力 $(D)$, 摩擦損失係数 $(f)$, 粗度係数 $(n)$ の計算結果

\begin{tabular}{|c|c|c|l|l|}
\hline \multicolumn{5}{|c|}{ Case 1 } \\
\hline & $\begin{array}{c}\text { Surface } \\
\text { area }\end{array}$ & \multicolumn{4}{|c|}{ Slope area } \\
\hline d & 0.01 & 0.0267 & 0.0433 & 0.600 \\
\hline$C_{d}$ & \multicolumn{5}{|c|}{1.246} \\
\hline D & \multicolumn{5}{|c|}{0.0218} \\
\hline f & \multicolumn{5}{|c|}{1.264} \\
\hline $\mathrm{n}$ & 0.0589 & 0.00694 & 0.0753 & 0.1166 \\
\hline
\end{tabular}

\begin{tabular}{|c|c|c|l|l|}
\hline \multicolumn{5}{|c|}{ Case 2 } \\
\hline & $\begin{array}{c}\text { Surface } \\
\text { area }\end{array}$ & \multicolumn{3}{|c|}{ Slope area } \\
\hline d & 0.02 & 0.0367 & 0.0533 & 0.700 \\
\hline C $_{\mathrm{d}}$ & \multicolumn{5}{|c|}{0.926} \\
\hline D & \multicolumn{5}{|c|}{0.0415} \\
\hline f & \multicolumn{5}{|c|}{0.939} \\
\hline $\mathrm{n}$ & 0.0570 & 0.0631 & 0.0672 & 0.1051 \\
\hline
\end{tabular}

Case 1 からCase 4 と水位が上昇するに従い，水制頭部と その上下流に流速差が発生しており，特に水制先端部で この傾向が顕著に現れていること，また水制下流側の死 水域が大きく変化していることが観察できる.

次に，先述した水制部の粗度係数を平面二次元流解 析に適用することで，評価した粗度係数よる再現性を検 証するために，図-6に示すメッシュ状に水制構造物を可

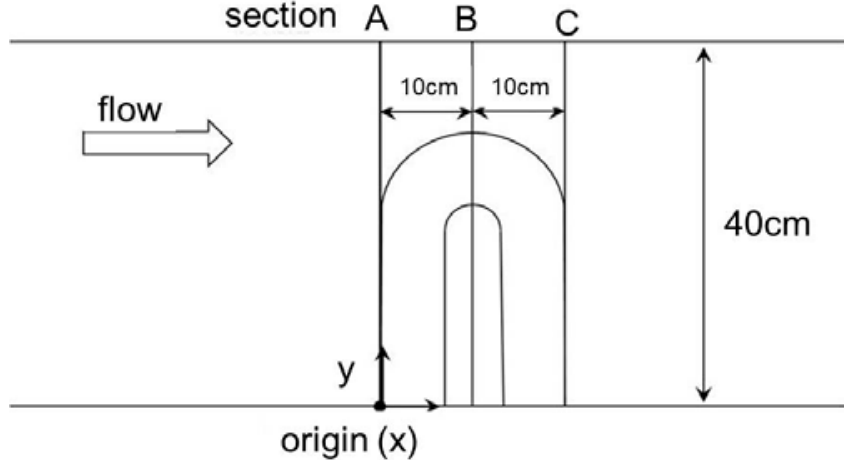

図-8 PTVIよる実験結果と平面二次元流解析の横断面流速分 布結果の比較・検証に用いた三つの横断面 $(A, B, C)$

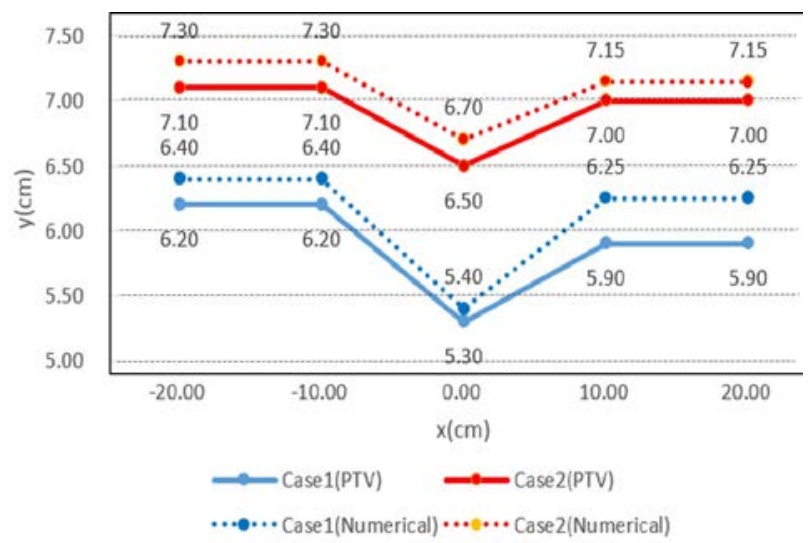

図-9 PTVおよび平面二次元流解析の水位結果の比較

視化実験と同じ設定で上流から3.5mの位置に配置し，図 -7に示す水制模型にあるグリッド状に粗度係数を設定し た. 図-1に示した水制形状に沿うように個々の地点で異 なる水位から，粗度係数を設定した。表-3にCase 1およ びCase 2 の越流水深 $(d)$, 抗力係数 $(C d)$, 抗力 $(D)$, 摩擦損 失係数 $(f)$, およびマニングの粗度係数 $(n)$ の計算結果を示 している. 本研究で適用した水制模型は頭部表面が平坦 で側面が傾斜を成していることから，それぞれSurface areaとSlope areaに分けて粗度係数を計算し, 平面二次元 流解析に適用した。 PTV解析から得られた結果と比較す るために水制上下流部における水位，また図-8に示す三 つの横断面(A,B,C)の平均流速の主流方向成分について 横断面分布の検証を行った. 図-9に，図-8に示したB断 面を基準とし上下流 $20 \mathrm{~cm}$ 前後， $10 \mathrm{~cm}$ 間隔の水位の変化 を表-3の2ケースについて示している．相互とも水制頭 部付近で水位が低下するといった減少傾向は捉えられて いる. 図-10は横断面内の主流方向成分の結果を示した ものである. なお，浅水流可視化実験では，水表面の流 速分布が得られるため, 数值計算の水深平均流速を対数 則の $1 / 3$ 付近に適用し表面流速に補正した值と比較を 行った. 越流水深の低いこれらの2ケースではA,B断面に おいて補正值とPTVの結果が同様な傾向が得られること が分かるが，C断面の水制先端付近で比較的越流水深の 小さなCase 1 の水表面でのPTV計測結果との違いが観ら 


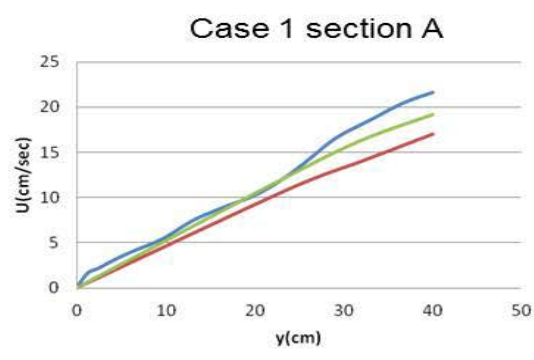

Case 1 section $B$

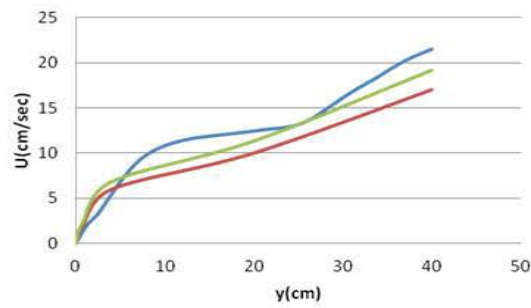

Case 1 section $C$

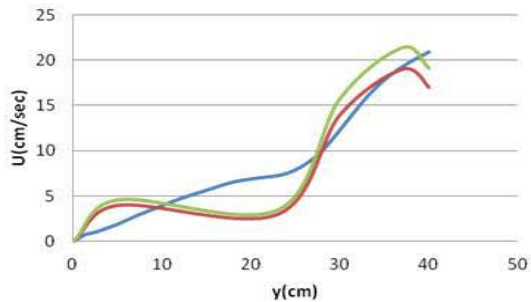

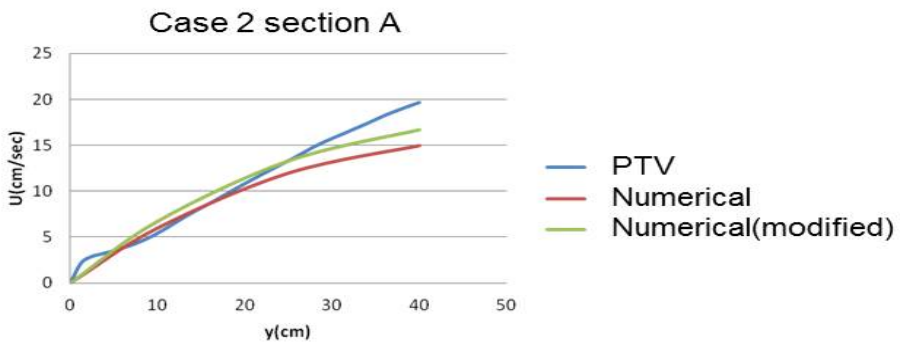

Case 2 section $B$

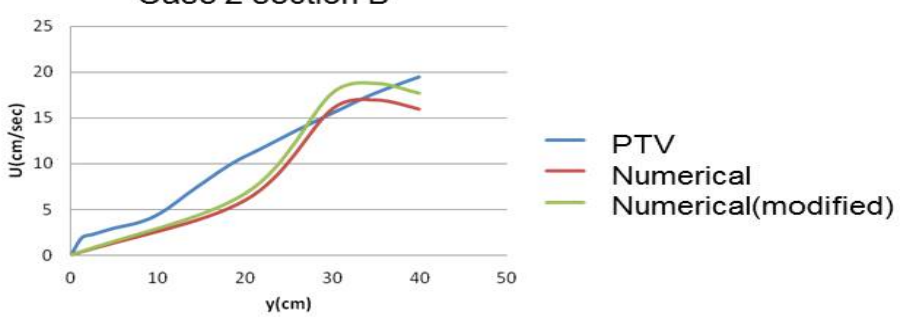

Case 2 section $C$

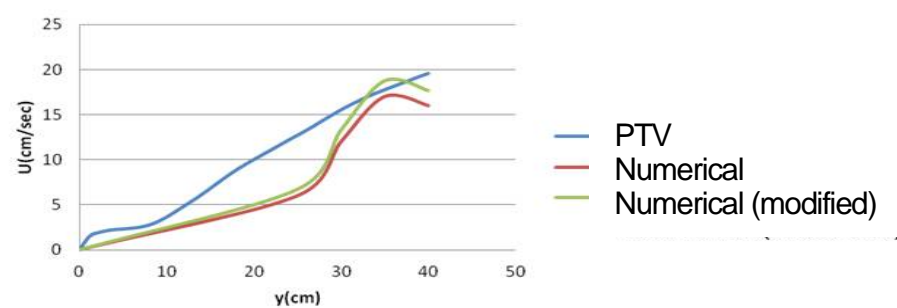

図-10 PTV実験結果と平面二次元流解析による横断面流速分布結果の比較

れる。この越流水深が低い領域では，特に壁面付近に局 所的な淀みが発生していることが原因で流速分布のずれ が生じていると考えられる.

\section{7. おわりに}

本研究では，越流型水制工における流れの抵抗特性に 関して，水制構造物が及ぼす抗力から水制の粗度係数を 導出・評価し，これらの結果を平面二次元流解析に適用 し，横断面内の流速分布を流れの可視化実験と比較する ことにより，その再現性を試みた。水制上流端から頭部 および水制下流端主流側には，再現性は確認できたと考 えられる．今後は実河川を対象とした適用性，特に連続 水制からなる越流型水制工についての展開，三次元流解 析での適応性の検討が必要であると考えられる.

\section{参考文献}

1) Chen, F-Y and Ikeda, S: Horizontal separation flows in shallow open channels with spur dikes, J. Hydroscience and Hydr. Eng. JSCE 15(2), pp.15-30, 1997.

2) Kimura, I. and Hosoda, T.: Fundamental properties of flows in open channels with dead zone, J. Hydr. Eng. ASCE, 123(2), pp.98-107, 1997.

3) Uijttewaal, W.S.J, Lehmann, D. and Mazijk, A. van: Exchange process between a river and its groyne fields: model experiments, $\mathrm{J}$. Hydr. Eng. ASCE, 127(11), pp.928-936, 2001.

4) Altai, W. and Chu V.H.: Retention time in a recirculating flow, Proc. XXVI IAHR congress, San Francisco, pp. 9-14, 1997.
5) Weitbrecht, V. and Jirka, G.H.J: Flow patterns and exchange processes in dead zones of rivers, Proc. 29th IAHR congress, Beijing, China, theme B, pp.439-445, 2001.

6) Garde, R.J., Subramanya, K. and Namburdripad, K.D.: Study of scour around spur dikes, J. Hydr. Div. ASCE 87(HY6), pp.23-37, 1961.

7) Gill, M.A.: Erosion of sand beds around spur-dikes, J. Hydr. Div. ASCE 98(HY9), pp.1587-1602, 1972.

8) Kuhnle, R.A., Alonso, C.V., Shields, F. D.: Local scour associated with angled spur dikes, J Hydr. Engrg ASCE 128(12), pp.1087-1093, 02002

9) Hentschel, B. and Anlauf, A: Ecological optimization of groynes in the Elbe river, New insights in the physical and ecological process in groyne fields, van Mazijk and Weibrecht eds., pp.121-133, 2002.

10) Klaassen, G.J., Douben, K. and van der Wal, M: Novel approaches in river engineering, Proc. Int. Conf. on Fluvial Hydraulics, Bousmar and Zech eds., Balkema, The Netherlands, pp.27-43, 2002.

11) Sukhodolov, A., Uijttewaal, W.S.J. and Engelhardt, C.: On the correspondence between morphologcal and hydrodynamical patterns of groyne fields, J. Earth Surf. Process Landforms, 27, pp. 289-936, 2002.

12) Maurits Kruijt: Resistance of submerged groynes, Master theses, TU Deflt, 2013.

13) Yossef, M.F.M: Morphodynamics of rivers with groynes, Delft University Press, TU Delft, 2005.

14) Van Broekhoven, R.W.A: Het effect van kribverlaging op de a fvoercapaciteit van de Waal ten tijde van hoogwater, TU Delft, 2007.

15) Anzifar, H.: Flow resistance and associated backwater effect due to spur dikes in open channels, University of Saskatchewan, Saskatoon, 2010.

（2014. 9. 30受付） 